\title{
Perbedaan Tingkat Kecemasan Siswa Kelas III SMA di Denpasar Ditinjau dari Efikasi Diri dan Keikutsertaan dalam Bimbingan Belajar Menjelang Ujian Nasional
}

\author{
Putu Winda Yuliantari Gunapriya Dharmapatni dan Supriyadi \\ Program Studi Psikologi, Fakultas Kedokteran, Universitas Udayana \\ windayuliantari@gmail.com
}

\begin{abstract}
Abstrak
Kecemasan menjelang Ujian Nasional menjadi hal yang sering dirasakan oleh siswa kelas III SMA. Kecemasan tidak hanya berdampak pada kondisi fisik, tetapi juga mempengaruhi aktivitas belajar siswa di sekolah dalam menghadapi Ujian Nasional. Tujuan penelitian ini adalah untuk mengetahui perbedaan tingkat kecemasan siswa kelas III SMA di Denpasar ditinjau dari efikasi diri dan keikutsertaan dalam bimbingan belajar menjelang Ujian Nasional.

Subjek penelitian ini adalah 266 siswa kelas III SMA di Denpasar yang terdiri dari siswa yang mengikuti dan tidak mengikuti bimbingan belajar (bimbel). Instrumen penelitian ini adalah skala kecemasan dan skala efikasi diri yang telah diuji kesahihan dan reliabilitas skalanya yaitu nilai alpha cronbach's skala kecemasan $=0.807$ dan nilai alpha cronbach's skala efikasi diri $=0.758$.

Hasil analisis kovarian menunjukkan $\mathrm{F}=66.953$; $\mathrm{p}<0.05$ yang berarti bahwa keikutsertaan dalam bimbingan belajar dan efikasi diri memiliki kontribusi terhadap kecemasan siswa kelas III SMA di Denpasar menjelang Ujian Nasional. Perbedaan kecemasan siswa berdasarkan keikutsertaan dalam bimbingan belajar secara signifikan menunjukkan angka uji beda $\mathrm{F}=17.578$; $\mathrm{p}<0.05$, yang berarti bahwa ada perbedaan tingkat kecemasan antara siswa yang ikut bimbel dengan yang tidak ikut. Sedangkan interaksi efikasi diri sebagai kovarian dengan kecemasan menunjukkan angka uji beda $\mathrm{F}=116.123$; $\mathrm{p}<0.05$. Hal ini menjelaskan bahwa efikasi diri signifikan berinteraksi dengan kecemasan. Kontribusi efikasi diri dan keikutsertaan dalam bimbingan belajar terhadap kecemasan menunjukkan angka adjusted $\mathrm{R}$ square sebesar 0.332 yang berarti bahwa efikasi diri dan keikutsertaan dalam bimbingan belajar dapat menjelaskan kecemasan siswa sebesar $33.2 \%$. Hasil juga menunjukkan bahwa keikutsertaan dalam bimbingan belajar tidak menjamin turunnya tingkat kecemasan pada siswa.
\end{abstract}

Kata Kunci : Kecemasan, Siswa Kelas III SMA, Efikasi Diri, Keikutsertaan dalam Bimbingan Belajar

\begin{abstract}
Anxiety before the National Exam often perceived by third grade high school students. Anxiety not only affect physical condition, but also student learning activities in school when preparing the National Exam. This study aims to find level differences of third grade high school student's anxiety in Denpasar in terms of self-efficacy and participation in tutoring before the National Exam

Subjects are 266 third grade high school students in Denpasar which consists of students who join and not join tutoring. The instrument of this research are anxiety and self-efficacy scale that has been tested the validity and reliability of the scale, with Cronbach's alpha values anxiety scale $=0.807$ and Cronbach's alpha values of self-efficacy scale $=0.758$.

Results of analysis covariance showed $\mathrm{F}=66.953 ; \mathrm{p}<0.05$, which means participation in tutoring and self-efficacy contributes to third grade high school students's anxiety in Denpasar towards the National Exam. Differences in student's anxiety based on participation in tutoring significantly indicates $\mathrm{p}=0.000(\mathrm{p}<0.05 ; \mathrm{F}=17.578)$, which means that there's differences in the level of anxiety among students who participate and didn't participate tutoring. While the interaction of self-efficacy as covariance with anxiety has a significance of $p=0.000(p<0.05 ; F=116.123)$ this showed that self-efficacy significantly interact with anxiety. The contribution of self-efficacy and participation in tutoring to anxiety showed the adjusted $\mathrm{R}$ square 0.332 which means that self-efficacy and participation in tutoring can explain the varians anxiety of student by $33.2 \%$. Results also showed that participation in the tutoring does not guarantee lower levels of student's anxiety.
\end{abstract}

Keywords: Anxiety, Third Grade High School Students, Self Efficacy, Opt in Tutoring 


\section{LATAR BELAKANG}

Pendidikan merupakan unsur terpenting dalam pembangunan. Sejalan dengan hal tersebut, proses pembangunan memerlukan adanya peningkatan mutu pendidikan nasional yang ditunjang oleh peningkatan sumber daya manusia yang berkualitas dan salah satunya diwujudkan melalui pelaksanaan Ujian Nasional. Salah satu yang menjalani ujian nasional adalah siswa kelas III SMA. Penilaian terhadap ujian nasional sayangnya tidak selalu positif di mata siswa khususnya kelas III SMA. Ujian nasional dipandang menakutkan sehingga muncul perasaan takut, cemas dan khawatir menjelang ujian.

Pelaksanaan Ujian Nasional diatur dalam Keputusan Menteri No. 153/U/2003 yang salah satunya mengatur tentang standar nilai kelulusan yang harus didapat oleh siswa untuk dapat melanjutkan pendidikan ke jenjang perguruan tinggi. Standar kelulusan ini setiap tahunnya mengalami peningkatan dari tahun 2003 sebesar 3,01 hingga tahun 2009 mencapai 5,50 dan terus bertahan hingga tahun 2013 (Eko dalam Yuwono, 2009). Namun bertahannya nilai standar kelulusan di angka 5,50 diikuti dengan berubahnya sistem Ujian Nasional melalui adanya penerapan paket soal yang berbeda. Pada tahun 2011 menerapkan 5 paket soal berbeda hingga tahun 2013 dengan 20 paket soal berbeda yang dimaksudkan untuk mengurangi tindak kecurangan dalam pelaksanaan ujian (Suryadi, 2013).

Nevid, dkk. (2005) mengungkapkan bahwa ujian merupakan salah satu sumber dari kecemasan yang dirasakan oleh siswa, selain itu pelaksanaan Ujian Nasional tidak bisa dipungkiri menimbulkan perasaan cemas dikalangan para siswa. Kecemasan pun meningkat ketika melihat peningkatan nilai standar kelulusan setiap tahunnya serta perubahan sistem pelaksanaan Ujian Nasional yang dilakukan untuk meningkatkan mutu pendidikan nasional dan kualitas dari siswa itu sendiri. Ant/Mba juga mengatakan, kecemasan banyak dirasakan siswa menjelang ujian nasional, sejumlah siswa di Palangkaraya mengaku cemas lantaran takut gagal ketika menghadapi ujian nasional (psikologizone.com, 2012).

Kecemasan dikatakan sebagai perasaan takut dan gundah yang tidak jelas dan sifatnya tidak menyenangkan bagi individu. Selain itu, kecemasan juga merupakan keadaan emosional yang memiliki ciri adanya rangsangan secara fisiologis dan perasaan tegang yang tidak menyenangkan bahwa sesuatu yang buruk akan terjadi (Santrock, 2007). Kecemasan merupakan bentuk respon terhadap ancaman yang kita rasakan, namun kecemasan dapat menjadi sesuatu yang sifatnya abnormal apabila tingkatannya tidak sesuai dengan proporsi dari ancaman yang datang, tanpa ada penyebabnya atau terjadi bukan karena respon yang muncul dari ancaman di lingkungan kita. Hal ini apabila secara ekstrem terjadi, dapat mengganggu kehidupan sehari-hari individu (Durand \& Barlow, 2006).
Kecemasan merupakan hal yang beriringan terjadi apabila berbicara mengenai pendidikan, dalam hal ini kegiatan di sekolah. Beberapa siswa akan mengalami rasa cemas sewaktu-waktu dalam menjalani aktivitasnya di sekolah, namun bagi beberapa siswa tersebut, rasa cemas dapat mengganggu proses belajar atau performa siswa di sekolah, terutama saat ujian (Cassady \& Johnson; Everson, Smodlaka \& Tobias dalam Slavin, 2009). Terkait dengan ujian, Santrock (2007) juga mengatakan siswa merasa cemas atau khawatir saat menghadapi kesulitan disekolah salah satunya menjelang ujian nasional.

Peneliti juga telah melakukan survei pendahuluan untuk mendukung latar belakang masalah yang disusun, dengan total 31 angket survei yang disebar ke siswa yang telah mengikuti Ujian Nasional pada bulan April 2014, baik yang mengikuti program bimbingan belajar maupun yang tidak mengikuti program bimbingan belajar. Berdasarkan survei yang telah disebar, didapatkan hasil sebanyak 27 responden mengikuti bimbingan belajar dan 4 responden tidak mengikuti bimbingan belajar. Perasaan cemas dialami oleh 30 responden yang mengisi angket sedangkan 1 responden mengatakan tidak merasa cemas. Perasaan cemas tersebut muncul karena rasa ketakutan tidak mampu menjawab soal-soal yang akan diujiankan seta adanya tuntutan untuk dapat lulus dengan nilai memuaskan agar dapat melanjutkan kuliah di perguruan tinggi.

Adanya perubahan sistem Ujian Nasional serta berkembangnya isu-isu seputar Ujian Nasional juga menjadi faktor yang mendorong kecemasan tersebut muncul. Seperti contohnya, pelaksanaan ujian nasional tahun 2013 dengan 20 macam paket soal mengalami peningkatan di tahun 2014 menjadi 30 macam paket soal, akan menambah beban psikologis siswa menjelang ujian. Kurang matangnya persiapan dalam hal kemampuan intelektual juga menjadi salah satu hal yang dirasa menambah rasa cemas akan perasaan tidak mampu menjawab soal ujian dan berdampak pada nilai yang tidak maksimal serta ketidaklulusan ujian nasional.

Didapatkan pula rentang waktu kecemasan tersebut muncul, dari 19 responden merasakan kecemasan kuat yang muncul seminggu sebelum ujian berlangsung, 1 responden merasa cemas yang kuat dua minggu sebelum ujian, 9 responden merasa cemas yang kuat muncul satu bulan sebelum ujian dan 1 responden sudah merasa cemas yang kuat sejak dua bulan sebelum pelaksanaan ujian nasional.

Kondisi tersebut membuat orangtua maupun siswa khususnya, mulai mempersiapkan diri dengan berbagai cara dimana salah satunya adalah belajar. Kegiatan belajar untuk persiapan ujian nasional tidak hanya dilakukan secara formal di sekolah melalui kegiatan belajar tambahan yang dinamakan dengan pembinaan sore untuk pelatihan atau pemantapan soal kisi-kisi ujian nasional. Beberapa siswa juga melakukan 
kegiatan belajar kelompok hingga mengikuti bimbingan belajar di luar kegiatan belajar sekolah.

Bimbingan belajar (bimbel) merupakan suatu bentuk sarana belajar tambahan di luar jam sekolah. Bimbel dikatakan sebagai suatu lembaga yang memfasilitasi siswa untuk lebih melengkapi pembelajaran yang sebelumnya sudah didapatkan di sekolah (Setyaningsih, dalam Nugroho 2010). Menjelang ujian, banyak orangtua siswa dan siswa sendiri berlomba untuk mengikuti bimbel sebagai bentuk antisipasi agar dapat menghadapi ujian dengan baik. Berdasarkan hasil survei yang dilakukan oleh Litbang Kompas pada November 2012, menunjukkan $87,8 \%$ dari 770 responden menyatakan bahwa pelajar perlu untuk mengikuti bimbingan belajar atau bimbel di luar sekolah. Bimbel diperlukan terutama untuk menambah pemahaman siswa pada materi pelajaran (Damanik, 2012).

Hanya saja tidak sedikit siswa yang memilih untuk belajar di rumah tanpa mengikuti bimbel dengan pertimbangan bahwa mereka merasa yakin akan kemampuan yang dimiliki dan hasil ujian dapat dicapai dengan maksimal tidak hanya dengan mengikuti bimbel, tapi lebih kepada serius dalam mengikuti pelajaran di kelas. Dalam sebuah artikel yang ditulis oleh Fauzy (2013), seorang siswa SMA Negeri di daerah Bandung mengungkapkan bahwa mengikuti bimbel merupakan hal yang sah-sah saja dilakukan, namun sebaiknya tidak sampai tergantung pada bimbel itu sendiri.

Bimbel dipandang sebagai pilihan terakhir yang seharusnya dipertimbangkan oleh siswa dan lebih yakin pada kemampuan diri dengan pelajaran yang didapat di sekolah. Selain itu, menurut pakar pendidikan Universitas Pendidikan Indonesia, Said Hamid Hasan, bimbel hanya mengajarkan jalan pintas dalam menjawab soal-soal ujian dan tidak mengembangkan kreativitas dalam menjawab soal-soal ujian tersebut (inilahkoran.com, 2013).

Disatu sisi hal ini dirasa sebagai suatu kelebihan oleh para siswa yang mengikuti bimbel karena bisa berlatih untuk memecahkan soal-soal ujian dengan cepat. Siswa akan sering diberikan soal-soal serta cara penyelesaian yang cepat dan tepat sehingga membuat siswa terbiasa dan terlatih mengerjakan soal. Hal ini juga membuat siswa memiliki keyakinan untuk dapat menyelesaikan soal-soal ujian dengan baik sehingga tidak merasakan cemas yang berlebihan ketika menghadapi ujian nasional. Bimbingan belajar tidak hanya dapat menurunkan kecemasan siswa menjelang Ujian Nasional tetapi juga memiliki kontribusi terhadap keyakinan diri siswa (Astuti dan Purwanto, 2014).

Efikasi diri diharapkan dapat memberikan siswa keyakinan akan kemampuan yang dimiliki dalam menyelesaikan baik itu tugas-tugas sekolah maupun ujian nasional sehingga hal ini dapat membuat siswa mengembangkan sikap positif terhadap kemampuan dirinya sendiri dan tidak cemas menghadapi tantangan yang dianggap berat seperti ujian nasional. Menurut Bandura, efikasi diri atau kecakapan diri merupakan pandangan individu akan kemampuannya dalam melakukan pekerjaan atau tugas tertentu (dalam Taylor, 2009). Kemauan kita untuk berusaha melakukan suatu pekerjaan atau mengejar tujuan tertentu dalam hidup, bergantung pada keyakinan yang kita miliki untuk melakukan pekerjaan atau tugas tersebut (Taylor, 2009). Bimbingan belajar membuat individu memiliki keyakinan untuk dapat mengerjakan tugas-tugas sekolah maupun soalsoal ujian dengan baik dan tepat karena bimbingan belajar tidak hanya memberikan manfaat secara akademik tetapi juga dalam kaitannya dengan kondisi psikologis siswa. Idealnya siswa yang mengikuti bimbingan belajar memiliki kesiapan yang baik untuk menghadapi ujian nasional sehingga tingkat kecemasan yang muncul menjelang ujian nasional pun rendah. Hal ini semakin didukung apabila siswa memiliki keyakinan diri yang tinggi untuk dapat menghadapi dan menyelesaikan soal-soal ujian nasional dengan baik dan sebaliknya (Rini, 2013., Astuti \& Purwanto, 2014.).

Berdasarkan uraian tersebut, maka peneliti tertarik untuk mengetahui lebih lanjut terkait perbedaan tingkat kecemasan siswa kelas III SMA di Denpasar ditinjau dari efikasi diri dan keikutsertaan dalam bimbingan belajar menjelang ujian nasional.

\section{Hipotesis Penelitian}

Terdapat hipotesis mayor dan minor dalam penelitian ini yaitu untuk hipotesis mayor apakah ada perbedaan tingkat kecemasan siswa kelas III SMA di Denpasar ditinjau dari efikasi diri dan keikutsertaan bimbingan belajar menjelang Ujian Nasional, sedangkan untuk hipotesis minor dalam penelitian ini ingin membuktikan apakah terdapat perbedaan efikasi diri ditinjau dari keikutsertaan bimbingan belajar serta apakah efikasi diri memiliki hubungan dengan kecemasan siswa kelas III SMA menjelang Ujian Nasional.

\section{METODE PENELITIAN}

\section{Variabel dan Definisi Operasional}

Variabel penelitian adalah suatu gejala yang sifatnya membedakan satu unsur dengan unsur yang lain dalam suatu populasi serta memiliki nilai yang bervariasi dan dapat diukur (Purwanto, 2008). Penelitian ini menggunakan tiga buah variabel yaitu keikutsertaan siswa kelas III SMA dalam program bimbingan belajar yang diselenggarakan oleh lembaga bimbingan belajar menjelang Ujian Nasional di Denpasar sebagai variabel bebas, kecemasan pada siswa kelas III SMA di Denpasar menjelang Ujian Nasional sebagai variabel tergantung dan efikasi diri siswa kelas III SMA di Denpasar menjelang Ujian Nasional sebagai kovariabel. 
Definisi operasional keikutsertaan bimbingan belajar adalah suatu bentuk kegiatan yang dilakukan oleh siswa di lembaga bimbingan belajar secara terus-menerus sebagai suatu upaya untuk menemukan cara belajar yang cepat dan tepat, dalam memilih program studi yang sesuai dengan kemampuan peserta didik dan dalam mengatasi kesulitan yang muncul terkait tuntutan belajar di institusi pendidikan untuk dapat mencapai prestasi yang baik dan maksimal yang diukur melalui pengelompokan status keikutsertaan pada kuisioner yaitu apakah siswa mengikuti bimbingan belajar atau tidak mengikuti bimbingan belajar.

Definisi operasional kecemasan adalah perasaan takut, khawatir, serta suatu bentuk keluhan akan terjadinya hal yang buruk, dalam hal ini dikaitkan dengan yang dirasakan siswa, yang diukur menggunakan skala kecemasan minimal 6 minggu sebelum ujian nasional. Terdapat dua dimensi kecemasan, yaitu state anxiety adalah kondisi emosional yang tidak menyenangkan karena persepsi individu saat mengalami situasi yang dirasa mengancam dan trait anxiety yang lebih mengarah kepada disposisi kepribadian yang dimiliki oleh individu secara umum dalam mempersepsikan lingkungan disekitarnya sebagai suatu hal yang mengancam.

Definisi operasional efikasi diri adalah keyakinan individu akan kemampuan dirinya dalam mengerjakan suatu tugas atau pekerjaan tertentu dan keyakinan akan mampu untuk mencapai tujuan tertentu yang dimiliki yang tersusun atas tiga dimensi yaitu level (tingkat kesulitan tugas), generality (keluasan bidang kerja) dan strenght (tingkat kematangan atau kemantapan individu). Variabel efikasi diri ini diukur dengan menggunakan skala efikasi diri.

\section{Subjek Penelitian}

Populasi diartikan sebagai wilayah generalisasi yang terdiri atas subyek atau obyek yang memiliki kualitas dan karakteristik tertentu yang ditetapkan oleh peneliti untuk dipelajari dan kemudian ditarik kesimpulannya (Sugiyono, 2013). Sedangkan sampel merupakan bagian dari suatu populasi yang memiliki kesamaan karakteristik dan dianggap dapat mewakili populasi (Sugiyono, 2013). Populasi dan sampel dalam penelitian ini adalah siswa kelas III SMA di Denpasar yang mengikuti dan tidak mengikuti program bimbingan belajar pada lembaga bimbingan belajar di luar sekolah.

\section{Teknik Pengambilan Sampel}

Teknik pengambilan sampel yang digunakan dalam penelitian ini adalah proportional random sampling, yaitu teknik pengambilan sampel dengan menentukan proporsi unsur-unsur atau kategori-kategori dalam populasi (Hadi, 1991). Proportional random sampling dilakukan dengan cara memilih beberapa sekolah di Denpasar secara random dimana peneliti terlebih dahulu mengumpulkan nama-nama SMA di Denpasar untuk kemudian memilih beberapa sekolah yang akan dijadikan tempat pengambilan sampel subjek.

Subjek penelitian akan diambil secara random dari beberapa sekolah yang terpilih secara proporsional, minimal sebanyak total 60 siswa yang mengikuti bimbel dan tidak mengikuti bimbel. Pengambilan banyak sampel didasarkan pada konsep statistika tradisional yang menganggap jumlah sampel yang lebih dari 60 orang sudah dianggap cukup banyak (Azwar, 2013).

\section{Alat Ukur Pengumpulan Data}

Alat ukur yang digunakan dalam penelitian ini berupa skala dengan model likert dan checklist. Skala yang digunakan adalah (1) skala kecemasan yang diadaptasi dari skala STAISpielberger dengan model checklist dan (2) skala efikasi diri yang diadaptasi dari skala Efikasi Diri Rustika (2014) dengan model Likert. Sedangkan keikutsertaan dalam bimbingan belajar diukur melalui pengelompokan status keikutsertaan siswa dalam bimbel yang dicantumkan pada lembar kuisioner. Pada skala kecemasan subjek akan diminta untuk menjawab pernyataan yang diberikan dengan mencantumkan tanda centang $(\sqrt{ })$ pada kolom pilihan "Ya" atau "Tidak". Ketentuan penilaian terhadap skala pengukuran kecemasan ini dengan memberikan skor 1 untuk pernyataan favorable dan skor 0 pada pernyataan unfavorable pada penilaian pilihan "Ya". Sedangkan untuk penilaian pilihan "Tidak" diberikan skor 0 untuk pernyataan favorable dan skor 1 untuk pernyataan unfavorable. Penentuan kecenderungan kecemasan subjek penelitian dilakukan dengan cara menjumlahkan hasil skor pada seluruh pernyataan yang telah dijawab. Semakin tinggi skor menunjukkan semakin tinggi tingkat kecemasan subjek. Sedangkan pada skala efikasi diri Subjek akan diminta untuk menjawab dengan memberikan tanda centang $(\sqrt{ })$ pada salah satu dari 4 pilihan jawaban yaitu "SS" atau sangat sesuai, "S" atau sesuai, "TS" atau tidak sesuai dan "STS" atau sangat tidak sesuai. Skala efikasi diri menggunakan penilaian dengan metode pendekatan Skala Likert dengan didasarkan pada jawaban subjek yang memiliki dua jenis pernyataan, yaitu aitem favorable dan aitem unfavorable. Pada aitem favorable pilihan jawaban "sangat sesuai" diberikan skor 4, pilihan "sesuai" diberikan skor 3, pilihan "tidak sesuai" diberikan skor 2 dan pilihan "sangat tidak sesuai" diberikan skor 1. Sedangkan pada aitem unfavorable pilihan jawaban "sangat sesuai" diberikan skor 1, pilihan "sesuai" diberikan skor 2, pilihan "tidak sesuai" diberikan skor 3 dan pilihan "sangat tidak sesuai" diberikan skor 4. Skor skala yang ditunjukkan berarti semakin tinggi skor menunjukkan semakin tinggi tingkat efikasi diri subjek. 
Validitas skala dalam penelitian ini yaitu validitas isi yang akan diuji melalui profesional judgement. Validitas isi merupakan validitas yang diestimasi melalui pengujian terhadap sejauh mana isi angket tersebut mencakup data yang komprehensif dan relevan dengan tujuan penelitian (Azwar, 1998). Sedangkan untuk validitas skala diestimasi melalui suatu koefisien diskriminan yang dinyatakan oleh korelasi antara distribusi skor aitem yang bersangkutan dengan distribusi skor total skala yang dilambangkan dengan riX. Validitas aitem dapat dikatakan baik dan memuaskan apabila memiliki batas minimum (riX) sebesar $>0,30$. Apabila jumlah aitem yang lolos masih tidak mencukupi jumlah yang diinginkan, dapat dilakukan pertimbangan untuk menurunkan batas kriteria menjadi 0.250 . Namun penurunan batas kriteria koefisien korelasi dibawah 0.200 sangat tidak disarankan (Azwar, 2013).

Sementara reliabilitas skala dalam penelitian ini menggunakan metode pendekatan konsistensi internal dengan teknik single trial administration untuk skala kecemasan (STAI Spielberger), yaitu metode pengujian akan konsistensi antar dimensi atau antar aitem dalam suatu alat ukur (Azwar, 2010). Perhitungan skala kecemasan menggunakan teknik perhitungan reliabilitas skor komposit. Uji reliabilitas skor komposit merupakan pengujian reliabilitas alat ukur yang didasarkan pada atribut alat ukur yang komposisinya dibentuk dari beberapa komponen yang berbeda (Azwar, 2013). Pengujian reliabilitas skor komposit terhadap alat ukur kecemasan State-Trait Anxiety Inventory cukup baik dilakukan karena komponen penyusun skala kecemasan ini terdiri atas dua komponen yang mengukur hal yang berbeda. Koefisien reliabilitas skala selanjutnya didapat menggunakan formula Mosier (Azwar, 2013). Sedangkan untuk skala efikasi diri, pengujian reliabilitas skala juga menggunakan teknik single trial administration yang dihitung melalui perhitungan statistik formula Cronbach's Alpha untuk melihat skor atau nilai reliabilitas skala. Reliabilitas suatu alat ukur dikatakan baik apabila koefisien reliabilitas alpha menunjukkan koefisien reliabilitas minimal 0.6. sehingga dapat dikatakan semakin besar nilai koefisien reliabilitas menunjukkan semakin reliabel alat ukur tersebut (Azwar, 2013).

Uji coba alat ukur dilakukan pada kedua skala yaitu skala kecemasan dan skala efikasi diri karena peneliti melakukan adaptasi dan modifikasi skala yang disesuaikan dengan kondisi serta kelompok subjek peneliti. Uji coba kedua skala ini dilakukan dengan menyebarkan skala ke 70 siswa yang di dua SMA di Denpasar pada bulan Pebruari dan Maret 2015. Jumlah aitem yang valid untuk skala kecemasan sebanyak 16 aitem dari 41 aitem dengan rentang koefisien korelasi aitem-total di setiap dimensinya yaitu state anxiety sejumlah enam aitem sebesar 0.335 - 0.570 dengan koefisien reliabilitas sebesar 0.712 dan trait anxiety sejumlah 10 aitem sebesar 0.248 - 0.641 dengan koefisien reliabilitas sebesar
0.781. Koefisien reliabilitas total untuk skala kecemasan ini dihitung dengan menggunakan formula skor komposit yaitu sebesar 0.807 .

Sedangkan untuk skala efikasi diri, jumlah aitem yang valid sebanyak 16 aitem dari 30 aitem dengan rentang koefisien aitem total sebesar 0.222 - 0.547 dengan koefisien reliabilitas skala efikasi diri sebesar 0.758 .

\section{Metode Pengumpulan Data}

Pengumpulan data dilakukan dengan mengurus surat izin penelitian terlebih dahulu ke Badan Penanaman Modal dan Perizinan Provinsi Bali, Kesbangpol Kota Denpasar, Disdikpora Kota Denpasar hingga mendapatkan izin di sekolah-sekolah yang menjadi tempat penelitian. Setelah itu peneliti mulai menyebarkan 350 buah kuisioner ke seluruh sampel penelitian di tiga sekolah SMA di Denpasar yang telah terpilih melalui proportional random sampling.

Berdasarkan data yang didapatkan, jumlah siswa yang mengikuti bimbingan belajar dan tidak mengikuti bimbingan belajar adalah sebanyak 739 . Rincian siswa yang mengikuti bimbel adalah sebagai berikut, 218 siswa di SMAN 3 Denpasar, 222 siswa di SMAN 4 Denpasar dan 299 siswa di SMAN 7 Denpasar. Sedangkan siswa yang tidak mengikuti bimbingan belajar sejumlah 251 siswa dengan rincian 50 siswa di SMAN 3 Denpasar, 36 siswa di SMAN 4 Denpasar dan 165 siswa di SMAN 7 Denpasar.

Tahap selanjutnya, peneliti menyebarkan sebanyak 350 skala kepada 245 siswa yang mengikuti bimbel dengan perhitungan 66 siswa di SMAN 3 Denpasar, 64 siswa di SMAN 4 Denpasar dan 115 siswa di SMAN 7 Denpasar serta 105 siswa yang tidak mengikuti bimbingan belajar dengan perhitungan 29 siswa di SMAN 3 Denpasar, 27 siswa di SMAN 4 Denpasar dan 49 siswa di SMAN 7 Denpasar. Tahapan berikutnya, peneliti melakukan skoring data dimana dari 350 skala yang tersebar dan berhasil dikumpulkan hanya 331 skala yang memenuhi syarat administrasi untuk dapat dilakukan data entry.

Setelah peneliti melakukan coding, skoring dan data entry sejumlah 331 skala, dilakukan cleaning data untuk membuang responden-responden yang tergolong memiliki skor ekstrem. Proses tersebut mendapatkan total 266 skala yang bisa dilakukan analisis data. Berdasarkan teknik perhitungan statistik tradisional (Azwar, 2013) sampel minimal untuk penelitian ini adalah sejumlah 60 subjek sedangkan sampel valid yang diperoleh oleh peneliti sejumlah 266 subjek sehingga dapat dikatakan bahwa penelitian ini sudah melebihi kriteria minimum sampel.

\section{Teknik Analisis Data}

Metode analisis data yang digunakan dalam penelitian ini dengan menggunakan teknik Analysis 


\section{PERBEDAAN TINGKAT KECEMASAN SISWA DITINJAU DARI EFIKAS DIRI DAN KEIKUTSERTAAN DALAM BIMBINGAN BELAJAR}

Covariance (ANCOVA) dengan bantuan program analisis statistik SPSS versi 16.0. Analysis Covariance (ANCOVA) digunakan karena terdapat variabel bebas (bukan utama) metrik yang digunakan sebagai kovariat dalam model, yaitu variabel efikasi diri sehingga perlu untuk dikontrol pengaruhnya terhadap interaksi variabel bebas (variabel keikutsertaan bimbingan belajar) dan variabel tergantung (variabel kecemasan) (Ghozali, 2011). Analisis digunakan untuk mengetahui perbedaan antara rata-rata dua atau lebih kelompok dalam variabel bebas terhadap variabel tergantung dengan adanya kontrol terhadap variabel bebas (bukan utama) atau yang disebut dengan kovariat (Salkind, 2010).

Sebelum melakukan analysis covariance, peneliti melakukan uji asumsi data terlebih dahulu untuk melihat apakah distribusi data yang digunakan dalam penelitian ini normal, homogen serta linier karena ketiga hal ini merupakan syarat untuk dapat digunakannya analysis covariance. Uji normalitas dilakukan untuk mengetahui normal atau tidaknya sebaran skor dari variabel kecemasan (Hadi, 1991). Salah satu uji normalitas yang digunakan untuk pengujian Analysis of Covariance adalah uji One Sample Kolmogorov Smirnov dengan standar pengambilan keputusan terhadap nilai signifikansi jika data berdistribusi normal adalah lebih dari $0.05(\mathrm{p}>0.05)$.

Demikian halnya dengan uji homogenitas data dimaksudkan untuk mengetahui kesamaan varians dari kedua kelompok. Jika kedua kelompok memiliki kesamaan varians, maka apabila nantinya kedua kelompok memiliki perbedaan, perbedaan tersebut memang benar disebabkan oleh rata-rata (mean) kemampuan bukan karena kesalahan random (Khasanah, dalam Kartika P., 2013). Tingkat signifikansi > 0,05 mengindikasikan data tersebut homogen. Dalam penelitian ini uji homogenitas menggunakan Levene's Test of homogenity of variance SPSS.

Sedangkan uji linearitas dilakukan untuk melihat apakah variabel-variabel dalam penelitian memiliki hubungan yang linier secara signifikan. Uji linearitas dalam penelitian ini menggunakan program SPSS yaitu pada bagian compare means yang menunjukkan seberapa jauh model penelitian menyimpang dari model linier. Uji linearitas dilakukan dengan menghitung nilai signifikansinya (p). Apabila nilai signifikansi yang diperoleh lebih kecil dari 0.05 ( $\mathrm{p}<0.05$ ) maka dapat dikatakan hubungan antara variabel kecemasan dan variabel efikasi diri adalah linier (Nurgiyantoro, B., Gunawan, \& Marzuki, 2009).

Uji hipotesis yang dilakukan dalam penelitian ini yaitu uji hipotesis mayor dengan menggunakan Analysis Covariance yang bertujuan untuk melihat perbedaan variabel tergantung yang ditinjau dari variabel bebas dengan adanya kontrol terhadap variabel bebas lain (kovariat). Dasar pengambilan keputusan dalam uji ini adalah jika hasil uji yang didapat, nilai signifikansinya lebih kecil dari 0,05 $(<0,05)$, maka hipotesis nol (Ho) yang diajukan dalam penelitian ini ditolak. Hal ini berarti hipotesis yang menyatakan tidak terdapat perbedaan terkait aspek yang ingin diukur antara kedua kelompok sampel dalam penelitian ini ditolak (Riduwan dkk., 2011).

Sedangkan untuk pengujian hipotesis minor dilakukan uji komparasi dengan perhitungan statistik Independent sample t-test dan uji regresi sederhana. Uji komparasi dengan perhitungan statistik Independent sample ttest digunakan untuk tujuan mengetahui perbedaan rata-rata (mean) antara dua kelompok sampel dari satu populasi (Santoso, 2003). Dasar pengambilan keputusan dalam uji ini adalah apabila nilai signifikansi $(\mathrm{p}<0.05)$ maka Ho ditolak dan sebaliknya bila nilai signifikansi $(p>0.05)$ maka Ho diterima.

Uji regresi sederhana digunakan untuk tujuan mengetahui arah hubungan antara variabel bebas dengan variabel tergantung serta untuk meramalkan nilai dari variabel tergantung apabila nilai dari variabel bebas mengalami kenaikan atau penurunan (Santoso, 2003). Uji statistik yang digunakan dalam model regresi ini adalah analisis regresi linier dengan bantuan SPSS. Fungsi regresi dapat ditinjau melalui goodness of fit yang secara statistik dapat diukur dari nilai koefisien determinasi (R2), nilai statistik $\mathrm{F}$ dan nilai statistik t. Perhitungan regresi linier secara statitik ini dapat dikatakan signifikan apabila nilai uji statistiknya menunjukkan bahwa Ho ditolak $(\mathrm{p}<0.05)$ dan sebaliknya dikatakan tidak signifikan apabila nilai uji statistiknya menunjukkan Ho diterima (Ghozali, 2012).

Interpretasi skor data juga dilakukan dalam penelitian ini, dengan cara mengkategorikan skor-skor yang diperoleh. Kategorisasi skor yang digunakan dalam penelitian ini adalah kategorisasi skor jenjang (ordinal) yang didasarkan pada nilai standar deviasi dan mean teoritik yang dilihat dari kurva normal (Azwar, 2013). Kategorisasi ini bertujuan untuk menempatkan individu ke dalam suatu kelompok-kelompok yang posisinya berjenjang menurut suatu kontinum berdasarkan atribut yang diukur (Azwar, 2013). Peneliti melakukan kategorisasi kedalam tiga kategori yaitu kategori rendah, kategori sedang dan kategori tinggi. Berikut merupakan formula dari kategorisasi skor penelitian :

Tabel 1.

Formula Kategorisasi Skor Penelitian

\begin{tabular}{ll|}
\hline Kategorisasi Skor & Rumus Kategori Skor \\
\hline Rendah & $\mathrm{x}<(\mu-1,0 \alpha)$ \\
Sedang & $(\mu-1,0 \alpha) \leq \mathrm{x}<(\mu+1,00)$ \\
Tinggi & $(\mu+1,00) \leq \mathrm{x}$ \\
\hline & Sumber: Penyulsunan Skala Psitologi (Azwar, 2013)
\end{tabular}

HASIL PENELITIAN 
Penelitian ini berhasil menganalisa data sejumlah 266 subjek yang terbagi ke dalam dua kelompok subjek yaitu kelompok yang mengikuti bimbingan belajar sebanyak 188 orang dan kelompok yang tidak mengikuti bimbingan belajar sebanyak 78 orang siswa SMA kelas III. Data karakteristik subjek dalam penelitian ini dijelaskan menurut jenis kelamin, keikutsertaan bimbingan belajar, rentang waktu mengikuti bimbingan belajar dan asal sekolah subjek. Rincian karakteristik tersebut dijelaskan dalam tabel 2 yaitu sebagai berikut:

\begin{tabular}{|c|c|c|c|}
\hline \multicolumn{4}{|c|}{$\begin{array}{c}\text { Tabel } 2 . \\
\text { Data karakteristik subjek dalam kategori dan persentase }\end{array}$} \\
\hline Karakteristik & Kategori & Jumlah Subjek & Persentase \\
\hline \multirow{2}{*}{ Jenis Kelamin } & Laki-laki & 129 & $48.5 \%$ \\
\hline & Perempuan & 137 & $51.5 \%$ \\
\hline \multirow{2}{*}{ Keikutsertaan Bimbel } & Ikut & 188 & $70.7 \%$ \\
\hline & Tidak Ikut & 78 & $29.3 \%$ \\
\hline \multirow{4}{*}{$\begin{array}{c}\text { Rentang Waktu } \\
\text { Mengikuti Bimbingan } \\
\text { Belajar } \\
\text { (dalam bulan) } \\
\end{array}$} & $1-12$ bulan & 154 & $57.9 \%$ \\
\hline & $13-24$ bulan & 12 & $4.5 \%$ \\
\hline & $25-36$ bulan & 22 & $8.3 \%$ \\
\hline & Missing Value & 78 & $29.3 \%$ \\
\hline \multirow{3}{*}{ Asal Sekolah } & SMAN 3 Denpasar & 69 & $25.9 \%$ \\
\hline & SMAN 4 Denpasar & 77 & $28.9 \%$ \\
\hline & SMAN 7 Denpasar & 120 & $45.1 \%$ \\
\hline
\end{tabular}

Pada deskripsi data penelitian ini, akan ditampilkan mengenai besaran mean, standar deviasi, jumlah subjek, skor terkecil dan skor terbesar. Deskripsi data penelitian tersebut dapat dilihat pada tabel 3 berikut ini :

\begin{tabular}{|c|c|c|}
\hline Deskripsi Data & $\begin{array}{c}\text { Kecemasan } \\
\text { (STAI Spielbergerer) }\end{array}$ & Efikasi Diri \\
\hline $\mathrm{N}$ & 266 & 266 \\
\hline Mean & 7.83 & 47.83 \\
\hline SD & 3.276 & 5.436 \\
\hline Xmin & 0 & 31 \\
\hline$X \max$ & 16 & 62 \\
\hline
\end{tabular}

Tingkat kecemasan dan efikasi diri dari subjek penelitian dapat dilihat dari mean teoritis dan mean empiris yang dapat dilihat dalam tabel 4 berikut:

Mean Teoritis, Mean Empiris dan Standar Deviasi

\begin{tabular}{ccc|}
\hline Deskripsi Data & $\begin{array}{c}\text { Kecemasan } \\
\text { (STAI Spielbergerer) }\end{array}$ & Efikasi Diri \\
\hline Mean Empiris & 7.83 & 47.83 \\
Mean Teoritis & 8.00 & 24 \\
SD Empiris & 3.276 & 5.436 \\
SD Teoritis & 1.333 & 4 \\
\hline
\end{tabular}

Kategorisasi skor penelitian dilakukan untuk membedakan kategori dari masing-masing variabel, sehingga dapat terlihat secara deskriptif kategori dari masing-masing variabel yang bersangkutan. Pada penelitian ini dilakukan kategorisasi tingkatan (rendah, sedang dan tinggi) pada variabel kecemasan (skala Kecemasan STAI Spielberger) dan juga pada variabel efikasi diri (skala Efikasi Diri) siswa kelas III SMA. Kategorisasi pada setiap variabel tersebut dapat dijelaskan sebagai berikut :
Tabel 5a.

Kategorisasi Skor Kecemasan

\begin{tabular}{|cccc|}
\hline Rentang & $\begin{array}{c}\text { Kategorisasi } \\
\text { Skor }\end{array}$ & Jumlah & Persentase \\
\hline $\mathrm{x}<7.3$ & Rendah & 125 & $47 \%$ \\
$7.3 \leq \mathrm{x}<9.3$ & Sedang & 55 & $21 \%$ \\
$9.3 \leq \mathrm{x}$ & Tinggi & 86 & $32 \%$ \\
Total & & 266 & \\
\hline
\end{tabular}

Pada tabel.5a. terlihat bahwa persentase paling besar pada kategorisasi skor rendah. Sedangkan yang paling kecil terletak pada kategori skor sedang yaitu sebesar $21 \%$. Sesuai dengan hasil perhitungan mean empiris yang lebih rendah dari hasil perhitungan mean teoritis, kecemasan siswa tergolong rendah yaitu sejumlah $47 \%$ subjek dominan berada pada kategori rendah.

\begin{tabular}{|c|c|c|c|c|c|}
\hline Rentang & $\begin{array}{l}\text { Kategorisasi } \\
\text { Skor }\end{array}$ & $\begin{array}{c}\text { Ikut } \\
\text { Bimbel }\end{array}$ & Persentase & $\begin{array}{c}\text { Tidak } \\
\text { Ikut } \\
\text { Bimbel }\end{array}$ & Persentase \\
\hline$x<7.3$ & Rendah & 75 & $40 \%$ & 50 & $64 \%$ \\
\hline $7.3 \leq x<9.3$ & Sedang & 43 & $23 \%$ & 12 & $15 \%$ \\
\hline $9.3 \leq \mathrm{x}$ & Tinggi & 70 & $37 \%$ & 16 & $21 \%$ \\
\hline Total & & 188 & $100 \%$ & 78 & $100 \%$ \\
\hline
\end{tabular}

Sedangkan jika dilihat dari kategorisasi berdasarkan kelompok subjek, peneliti menemukan persentase kecemasan paling besar di kelompok subjek yang mengikuti bimbel terletak pada kategori rendah yaitu sebesar $40 \%$ dan demikian pula halnya dengan kelompok subjek yang tidak ikut bimbel kategorisasi paling besar persentasenya yaitu pada kategori rendah sebesar 64\%. Persentase terendah terletak pada kategori skor sedang yaitu sebesar $23 \%$ pada kelompok subjek yang ikut bimbel dan $15 \%$ pada kelompok subjek yang tidak ikut bimbel:

Tabel 6

Kategorisasi Skor Efikasi Diri

\begin{tabular}{|cccc|}
\hline Rentang & Kategorisasi Skor & Jumlah & Persentase \\
$\mathrm{x}<20$ & Rendah & 0 & $0 \%$ \\
$20 \leq \mathrm{x}<28$ & Sedang & 0 & $0 \%$ \\
$28 \leq \mathrm{x}$ & Tinggi & 266 & $100 \%$ \\
Total & & 266 & $100 \%$ \\
\hline
\end{tabular}

Berdasarkan kategorisasi skor efikasi diri yang dilakukan, peneliti menemukan persentase kategorisasi skor berada pada skor tinggi sebesar $100 \%$. Hal ini sesuai dengan hasil perhitungan mean empiris yang lebih tinggi dari hasil perhitungan mean teoritis, efikasi diri siswa tergolong tinggi yaitu sebesar $100 \%$ subjek berada pada kategori tinggi.

Analisis data yang dilakukan peneliti menggunakan analysis covariance dimana sebelum dilakukannya analisis tersebut, peneliti terlebih dahulu melakukan uji asumsi yang meliputi uji normalitas, uji homogenitas dan uji linearitas yang merupakan syarat untuk uji analysis covariance (ANCOVA). Uji normalitas dan uji homogenitas pada dua kelompok sampel dengan jumlah berbeda yaitu sampel yang berjumlah 
266 subjek dan 156 subjek. Sampel 156 subjek merupakan sambel dengan jumlah kelompok sampel bimbel maupun non bimbel yang setara. Hasil uji normalitas maupun homogenitas dapat dilihat pada tabel $7 \mathrm{a}$ dan $7 \mathrm{~b}$ berikut:

Tabel 7a.

Uji Normalitas Sebaran Data Kecemasan dan Efikasi Diri (n=266)

\begin{tabular}{|cccc|}
\hline Jenis Data & $\begin{array}{c}\text { Kolmogorov- } \\
\text { Smirnov }\end{array}$ & $\mathbf{P}$ & Kesimpulan \\
\hline Kecemasan & 1.142 & 0.147 & Normal \\
Efikasi Diri & 1.349 & 0.053 & Normal \\
\hline \multicolumn{4}{c}{ Tabel 7b. } \\
Uji Normalitas Sebaran Data Kecemasan dan Efikasi Diri (n=156) \\
\hline Jenis Data & $\begin{array}{c}\text { Kolmogorov- } \\
\text { Smirnov }\end{array}$ & $\mathbf{P}$ & Kesimpulan \\
\hline Kecemasan & 0.869 & 0.437 & Normal \\
Efikasi Diri & 1.229 & 0.098 & Normal \\
\hline
\end{tabular}

Hasil pada table $7 \mathrm{a}$ dan tabel $7 \mathrm{~b}$ diatas menunjukkan bahwa pada $n$ sampel yaitu sebanyak 266, variabel kecemasan dan efikasi diri dalam penelitian ini mempunyai data yang berdistribusi normal dengan rincian berdasarkan nilai kolmogorov-smirnov data kecemasan memiliki nilai sebesar 1.147 (Zhitung < 1.96) dengan signifikansi (p) sebesar 0.147 ( $>0.050$ ). Begitu pula dengan data efikasi diri memiliki nilai kolmogorov-smirnov sebesar 1.349 (Zhitung < 1.96) dengan nilai signifikansi (p) sebesar $0.053(\mathrm{p}>0.050)$. Serta pada $\mathrm{n}$ sampel sebanyak 156 (dengan $n$ kelompok sebanyak 78 ditiap kelompok), variabel dalam penelitian juga memiliki distribusi yang normal berdasarkan nilai kolmogorov-smirnov data kecemasan memiliki nilai sebesar 0.869 (Zhitung < 1.96) dengan signifikansi ( $p$ ) sebesar 0.437 ( $p>0.05$ ). Begitu pula dengan data efikasi diri memiliki nilai kolmogorov-smirnov sebesar 1.229 (Zhitung < 1.96) dengan nilai signifikansi (p) sebesar 0.098 ( $p>0.050)$.

Uji homogenitas dimaksudkan untuk mengetahui kesamaan varians dari kedua kelompok. Jika kedua kelompok memiliki kesamaan varians, maka apabila nantinya kedua kelompok memiliki perbedaan, perbedaan tersebut memang benar disebabkan oleh rata-rata (mean) kemampuan bukan karena kesalahan random (Khasanah, dalam Kartika P., 2013). Rincian hasil uji homogenitas dapat dilihat pada tabel $8 \mathrm{a}$ dan 8 b berikut:

\begin{tabular}{|c|c|c|c|}
\hline \multicolumn{4}{|c|}{$\begin{array}{l}\text { Tabel 8a. } \\
\text { Uji Homogenitas Data Kecemasan }\end{array}$} \\
\hline n Sampel & Levene Statistic & p & Kesimpulan \\
\hline 266 & 0.082 & 0.775 & Homogen \\
\hline 156 & 0.090 & 0.764 & Homogen \\
\hline \multicolumn{4}{|c|}{$\begin{array}{c}\text { Tabel 8b. } \\
\text { Uji Homogenitas Data Efikasi Diri }\end{array}$} \\
\hline n Sampel & Levene Statistic & p & Kesimpulan \\
\hline 266 & 1.849 & 0.175 & Homogen \\
\hline 156 & 1.155 & 0.284 & Homogen \\
\hline
\end{tabular}

Pada tabel 8a dan 8b dapat dilihat $\mathrm{n}$ sampel sebanyak 266 dengan nilai Levene Statistic sebesar 0.082 dan nilai signifikansi (p) sebesar 0.775 . Nilai signifikansi yang lebih besar dari $0.05(\mathrm{p}>0.05)$ dapat dikatakan sebagai nilai yang menunjukkan bahwa varians data dalam kelompok kecemasan adalah sama atau homogen. Pada $\mathrm{n}$ sampel sebanyak 156 (dengan $\mathrm{n}$ kelompok sebanyak 78 ditiap kelompok) memiliki nilai Levene Statistic sebesar 0.090 dan nilai signifikansi (p) sebesar 0.764. Nilai signifikansi yang lebih besar dari $0.05(\mathrm{p}$ $>0.05$ ) dapat dikatakan sebagai nilai yang menunjukkan bahwa varians data dalam kelompok kecemasan adalah sama atau homogen.

Begitu pula dengan varians data efikasi diri. Terlihat pada tabel $\mathrm{n}$ sampel sebanyak 266 memiliki nilai Levene Statistic sebesar 1.849 dengan signifikansi sebesar $\mathrm{p}=0.175$ ( $>>0.05$ ). Pada tabel dengan $n$ sampel sebanyak 156 nilai Levene Statistic juga menunjukkan angka sebesar 1.155 dengan signifikansi sebesar $\mathrm{p}=0.284 \quad(\mathrm{p}>0.05)$. Nilai signifikansi yang lebih besar dari 0.05 menunjukkan bahwa varians data dalam kelompok efikasi diri adalah sama atau homogen.

Selanjutnya pengujian linearitas dilakukan untuk melihat apakah variabel-variabel dalam penelitian memiliki hubungan yang linier secara signifikan. Rincian hasil uji linearitas dapat dilihat pada table $9 \mathrm{a}$ dan $9 \mathrm{~b}$ berikut :

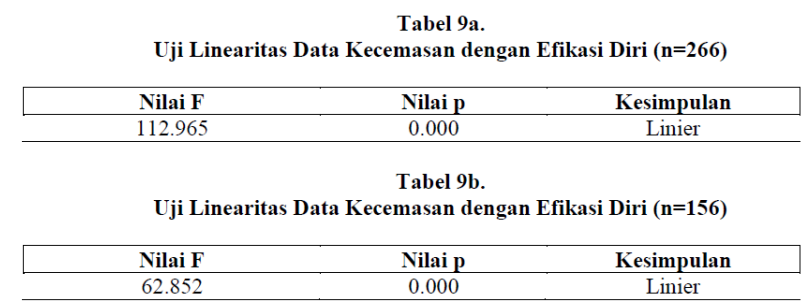

Pada tabel 9a dan 9b dapat dilihat bahwa pada $n$ sampel 266 dan 156 menunjukkan hasil bahwa variabel kecemasan memiliki hubungan yang linier dengan variabel efikasi diri dimana nilai signifikansi (p) menunjukkan nilai sebesar $0.000(\mathrm{p}<0.05)$.

Terdapat dua pengujian hipotesis dalam penelitian ini, pertama pengujian hipotesis mayor dengan Analysis Covariance (ANCOVA). Analysis Covariance yang dilakukan dalam penelitian ini bertujuan untuk melihat perbedaan variabel tergantung yang ditinjau dari variabel bebas dengan adanya kontrol terhadap variabel bebas lain (kovariat). Hal ini dijelaskan lebih rinci pada tabel 10a perhitungan statistik ANCOVA berikut: 


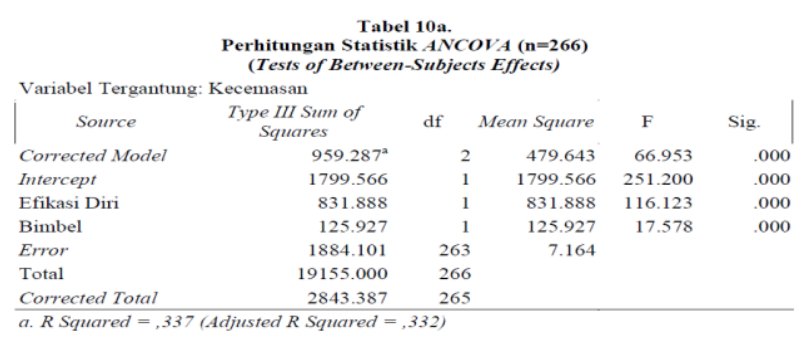

Pada bagian Corrected Model menunjukkan nilai signifikansi (p) sebesar 0.000 dimana nilai tersebut berada dibawah $0.05(\mathrm{p}<0.05)$ sehingga dapat dikatakan bahwa Ho ditolak. Hasil ini menunjukkan bahwa pada tingkat kepercayaan 95\% efikasi diri serta keikutsertaan bimbingan belajar memiliki kontribusi terhadap kecemasan siswa menjelang ujian nasional. Besarnya nilai Adjusted R Squared 0.332 memiliki arti bahwa variabel kecemasan yang dapat dijelaskan oleh variabel keikutsertaan bimbingan belajar dan efikasi diri adalah sebesar $33.2 \%$.

Nilai Adjusted R Squared mengalami peningkatan dari sebelum dilakukannya kontrol terhadap efikasi diri. Sebelum dilakukan kontrol terhadap efikasi diri, nilai Adjusted R Squared kecemasan ditinjau dari keikutsertaan bimbingan belajar hanya sebesar 0.041 yang berarti bahwa variabel kecemasan hanya dapat dijelaskan oleh variabel keikutsertaan bimbingan belajar sebesar $4.1 \%$. Adanya kenaikan setelah dilakukan kontrol terhadap efikasi diri menandakan bahwa model menjadi lebih baik. Berikut tabel $10 \mathrm{~b}$ perhitungan statistik ANOVA tanpa adanya kontrol terhadap efikasi diri:

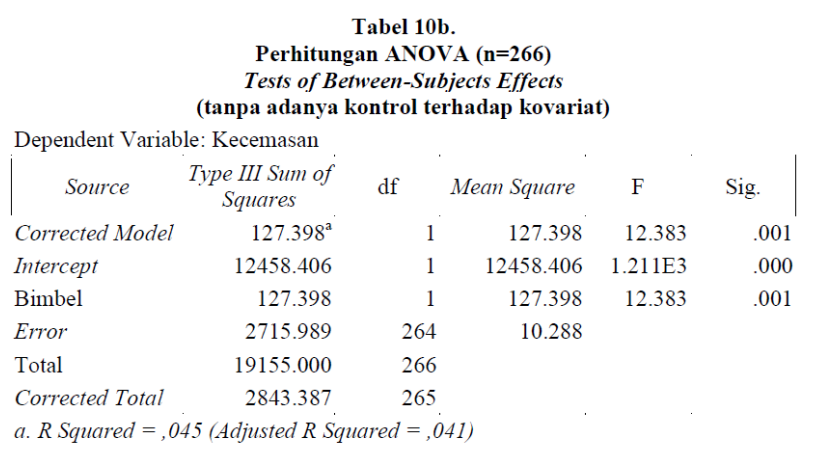

Analysis Covariance juga dilakukan pada sampel subjek 156 orang dengan jumlah di tiap kelompok subjek yang setara dengan tujuan untuk meyakinkan peneliti bahwa hasil yang akan ditunjukkan juga sama. Rincian hasil analisis dapat dilihat pada tabel 11a berikut:

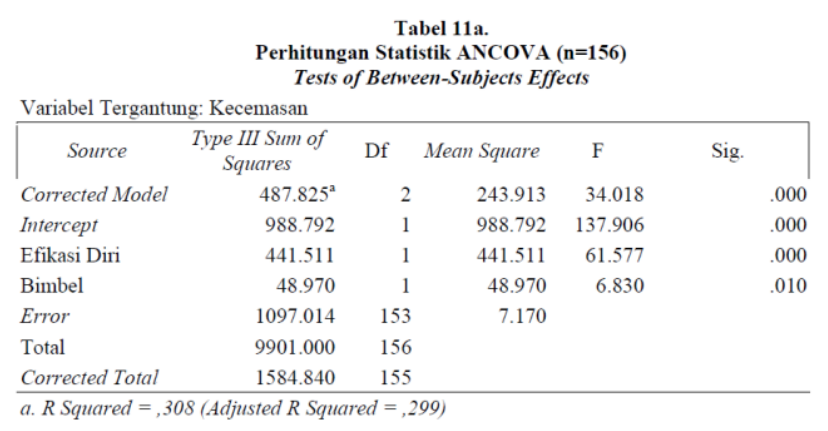

Pada bagian Corrected Model menunjukkan nilai signifikansi (p) sebesar 0.000 dimana nilai tersebut berada dibawah $0.05(\mathrm{p}<0.05)$ sehingga dapat dikatakan bahwa Ho ditolak. Hasil ini menunjukkan bahwa pada tingkat kepercayaan 95\% efikasi diri serta keikutsertaan bimbingan belajar memiliki kontribusi terhadap kecemasan siswa menjelang ujian nasional. Besarnya nilai Adjusted R Squared 0.299 memiliki arti bahwa variabel kecemasan yang dapat dijelaskan oleh variabel keikutsertaan bimbingan belajar dan efikasi diri adalah sebesar $29.9 \%$.

Nilai Adjusted R Squared mengalami peningkatan dari sebelum dilakukannya kontrol terhadap efikasi diri. Sebelum dilakukan kontrol terhadap efikasi diri, nilai Adjusted R Squared kecemasan ditinjau dari keikutsertaan bimbingan belajar hanya sebesar 0.023 yang berarti bahwa variabel kecemasan hanya dapat dijelaskan oleh variabel keikutsertaan bimbingan belajar sebesar 2.3\%. Adanya kenaikan setelah dilakukan kontrol terhadap efikasi diri menandakan bahwa model menjadi lebih baik. Berikut tabel 11b perhitungan statistik ANOVA tanpa adanya kontrol terhadap efikasi diri:

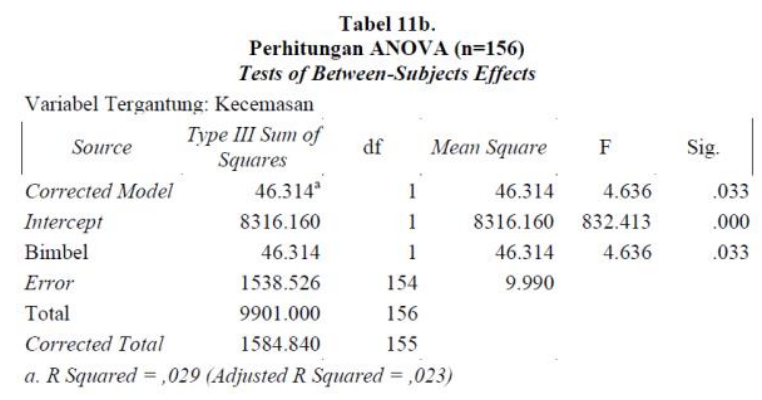

Pengujian hipotesis kedua adalah uji hipotesis minor yaitu uji komparasi dan regresi sederhana. Pada uji hipotesis minor, variabel efikasi diri dilihat sebagai variabel tergantung yang nantinya ditinjau dari keikutsertaan bimbingan belajar. Hal ini bertujuan untuk mengetahui apakah terdapat perbedaan efikasi diri antara subjek yang mengikuti bimbingan belajar dan tidak mengikuti bimbingan belajar. Selain itu ingin diketahui juga bagaimana hubungan antara efikasi diri dengan kecemasan siswa sebagai bentuk eksplorasi temuan pada hipotesis mayor. 


\section{PERBEDAAN TINGKAT KECEMASAN SISWA DITINJAU DARI EFIKAS DIRI DAN KEIKUTSERTAAN DALAM BIMBINGAN BELAJAR}

Analisis komparasi parametrik yang digunakan untuk menganalisis perbedaan ini adalah uji independent sample ttest. Uji independent sample t-test merupakan uji komparasi yang bertujuan untuk melihat perbedaan rata-rata antara dua kelompok populasi dengan melihat rata-rata sampelnya (Santoso, 2003). Hasil Uji Komparasi Independent Sample ttest yang dilakukan dapat dilihat pada tabel 12a berikut:

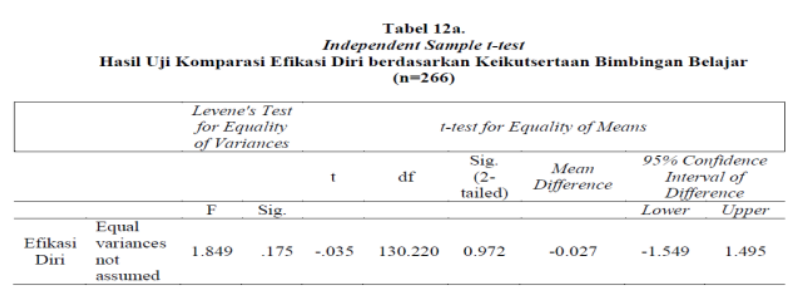

Pada table 12a diatas telihat bahwa hasil t-test menunjukkan angka sebesar $\mathrm{p}=0.972(\mathrm{p}>0.05)$ yang berarti bahwa kedua rata-rata kelompok tidak memiliki perbedaan efikasi diri atau dengan kata lain, rata-rata efikasi diri antara subjek yang mengikuti bimbingan belajar dan subjek yang tidak mengikuti bimbingan belajar adalah identik. Levene's test of homogeneity yang dibaca adalah pada bagian not equal karena jumlah subjek pada tiap kelompok tidak setara.

Pada $\mathrm{n}$ sampel yang setara, yaitu tiap kelompok terdiri atas 78 orang menunjukkan hasil uji komparasi dengan menggunakan independent sample t-test sebagai berikut:

\begin{tabular}{|c|c|c|c|c|c|c|c|c|c|}
\hline & Hasil Uji K & Compar & si Efil & $\begin{array}{l}\text { Inde } \\
\text { si Diri }\end{array}$ & $\begin{array}{l}\text { abel } 1 \\
\text { dent } S a \\
\text { rdasar } \\
(\mathrm{n}=15\end{array}$ & $\begin{array}{l}\text { iple t-tes } \\
\text { an Keik }\end{array}$ & sertaan Bin & bingan $B$ & lajar \\
\hline & & $\begin{array}{l}\text { Leven } \\
\text { for Eo } \\
\text { of Var }\end{array}$ & $\begin{array}{l}\text { S Test } \\
\text { Iality } \\
\text { ances }\end{array}$ & & & est for $\mathrm{E}$ & uality of Me & & \\
\hline & & & & $\mathrm{T}$ & df & $\begin{array}{l}\text { Sig. } \\
(2- \\
\text { tailed) }\end{array}$ & $\begin{array}{c}\text { Mean } \\
\text { Difference }\end{array}$ & $\begin{array}{r}95 \% \mathrm{Cc} \\
\text { Inter } \\
\text { Diffe }\end{array}$ & $\begin{array}{l}\text { fidence } \\
\text { al of } \\
\text { ence }\end{array}$ \\
\hline & & $F$ & Sig. & & & & & Lower & Upper \\
\hline $\begin{array}{l}\text { Efikasi } \\
\text { Diri }\end{array}$ & $\begin{array}{l}\text { Equal } \\
\text { Variances } \\
\text { Assumed }\end{array}$ & 1.155 & .284 & .114 & 154 & 0.910 & 0.103 & -1.678 & 1.883 \\
\hline
\end{tabular}

Pada tabel $12 \mathrm{~b}$ diatas telihat bahwa signifikansi t-test sebesar $\mathrm{p}=0.910(\mathrm{p}>0.05)$ yang berarti bahwa kedua rata-rata kelompok tidak memiliki perbedaan efikasi diri atau dengan kata lain, rata-rata efikasi diri antara subjek yang mengikuti bimbingan belajar dan subjek yang tidak mengikuti bimbingan belajar adalah identik.

Pengujian hipotesis minor yang kedua adalah uji regresi untuk variabel efikasi diri terhadap kecemasan. Uji analisis data menggunakan regresi sederhana dilakukan tidak hanya untuk melihat keeratan hubungan antar variabel tetapi juga untuk memprediksi hubungan antar variabel (Santoso, 2003). Hasil uji regresi linier yang dilakukan dapat dilihat pada table 13a berikut:
Tabel 13a.

Hasil Regresi Linier antara Kecemasan dengan Efikasi Diri

\begin{tabular}{|ccccc|}
\hline $\begin{array}{c}\text { Coefficient } \\
\text { Regression }\end{array}$ & $R$ Square & $\begin{array}{c}\text { Std. Error of } \\
\text { Estimate }\end{array}$ & F & Sig. \\
\hline 0.326 & 0.293 & 2.759 & 109.455 & 0.000 \\
\hline
\end{tabular}

Pada table 13a diatas dapat dilihat bahwa koefisien regresi antara kecemasan dengan efikasi diri sebesar 0.326 dengan $\mathrm{R}$ square sebesar 0.293 yang berarti bahwa $29.3 \%$ variabel kecemasan dapat dijelaskan oleh variabel efikasi diri. Nilai standar error of estimate sebesar 2.759. Nilai ini menunjukkan seberapa tepat model regresi mampu memprediksi variabel tergantung. Semakin kecil nilai standar error of estimate akan membuat model regresi semakin tepat dalam memprediksi variabel tergantung (Ghozali, 2011). Nilai F hitung sebesar 109.455 dengan signifikansi (p) sebesar $0.000(\mathrm{p}<0.05)$ sehingga dapat dikatakan bahwa efikasi diri dapat digunakan untuk memprediksi variabel kecemasan.

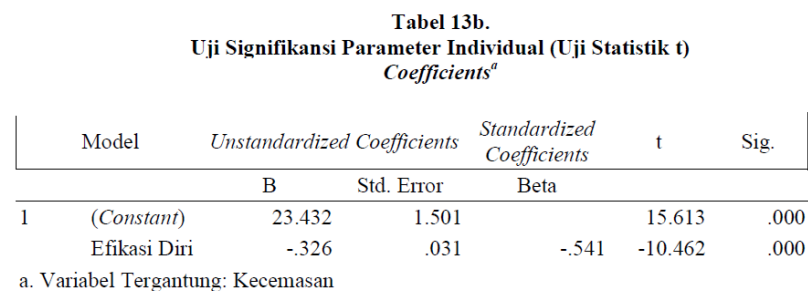

Tabel 13b diatas menunjukkan interpretasi terhadap koefisien variabel bebas yang dilihat menggunakan unstandardized coefficients. Terlihat bahwa variabel efikasi diri memiliki nilai yang signifikan dimana probabilitas signifikansinya lebih kecil dari $0.05(\mathrm{p}<0.05)$. Sehingga dari tabel tersebut dapat disimpulkan bahwa variabel efikasi diri memiliki hubungan yang kausal dengan variabel kecemasan. Nilai koefisien regresi yang bertanda negatif memiliki arti bahwa semakin tinggi efikasi diri hal ini akan membuat kecemasan subjek cenderung turun

\section{PEMBAHASAN DAN KESIMPULAN}

Berdasarkan hasil Analysis Covariance menunjukkan adanya perbedaan kecemasan siswa kelas III SMA menjelang ujian nasional ditinjau dari efikasi diri dan keikutsertaan bimbingan belajar dengan nilai $F$ test sebesar 66.953 dan signifikansi sebesar $0.000 \quad(\mathrm{p}<0.05)$. Setelah dilakukan penelusuran secara mendalam terkait kelompok subjek mana yang lebih cemas, secara statistik kelompok subjek yang mengikuti bimbingan belajar memiliki rata-rata kecemasan yang lebih tinggi dibandingkan kelompok subjek yang tidak mengikuti bimbingan belajar. Hal ini dapat disimpulkan bahwa keikutsertaan bimbingan belajar tidak sepenuhnya dapat menurunkan kecemasan siswa menjelang ujian nasional. 
Apabila siswa menilai pendidikan yang harus mereka selesaikan terkait ujian nasional sebagai suatu tantangan, hal ini akan memunculkan kompetensi individu dan meningkatkan keinginan individu untuk belajar. Sebaliknya, apabila siswa menjalani pendidikan dan melihat ujian nasional sebagai suatu ancaman hal ini akan memunculkan sikap tidak percaya diri dan ketidakmampuan (Lazarus dalam Kumaraswamy, 2013). Sehingga meskipun siswa mengikuti bimbingan belajar, apabila tidak memiliki penilaian yang positif terhadap ujian nasional hal tersebut tidak akan memberikan kontribusi yang besar terhadap kecemasan itu sendiri.

Peneliti juga menganalisa data tambahan untuk tiap dimensi dalam kecemasan yaitu state anxiety dan trait anxiety. Hal ini dimaksudkan untuk melihat apakah dari segi dimensi penyusun kecemasan, terdapat perbedaan yang dapat membantu menjelaskan tingginya tingkat kecemasan di kelompok siswa yang ikut bimbingan belajar. Hasil analisis menunjukkan dari data state anxiety tidak terdapat perbedaan antara yang mengikuti bimbingan belajar dan tidak mengikuti bimbingan belajar. Nilai signifikansi menunjukkan angka $0.073>0.05$ setelah diuji menggunakan Mann Whitney karena data tidak normal. Sedangkan hasil analisis untuk data trait anxiety menunjukkan terdapat perbedaan antara yang mengikuti bimbingan belajar dengan yang tidak mengikuti bimbingan belajar. Nilai signifikansi menunjukkan angka $0.001<0.05$ setelah diuji menggunakan Mann Whitney. Nilai mean rank trait anxiety siswa yang mengikuti bimbingan belajar ternyata lebih tinggi yaitu sebesar 177.47 dibandingkan kelompok siswa yang tidak mengikuti bimbingan belajar yaitu hanya sebesar 139.13.

Hasil pengujian ini menunjukkan bahwa trait anxiety yang lebih berperan pada tingginya skor kecemasan dari siswa yang mengikuti bimbingan belajar. Trait anxiety menurut Spielberg (2006) merupakan suatu disposisi kepribadian yang dimiliki individu dalam mempersepsi suatu keadaan sebagai kondisi yang mengancam. Kecemasan siswa dapat dikatakan lebih dikarenakan oleh bawaan perasaan cemas yang dimiliki oleh masing-masing individu. Hal ini sejalan dengan apa yang disampaikan oleh Lazarus (dalam Kumaraswamy, 2013) dan O’Connor (dalam Pratiwi, 2009) yaitu apabila siswa sedari awal melihat dan mempersepsikan ujian nasional sebagai suatu ancaman, hal ini akan membuat siswa memiliki rasa tidak percaya diri dan memunculkan kecemasan, ditambah lagi dengan rutinitas dalam bimbingan belajar yang menurut O'Connor menjadi salah satu faktor yang meningkatkan intensitas cemas dari individu.

Keikutsertaan bimbingan belajar tidak hanya menjadi satu-satunya faktor penentu tinggi rendahnya atau cemas tidaknya siswa dalam menghadapi ujian nasional. Hal ini didukung oleh hasil penelitian yang menunjukkan bahwa kontribusi bimbingan belajar hanya sebesar $4.1 \%$. Kontribusi tersebut dapat dilihat dari kegiatan pembahasan soal-soal latihan yang dilakukan oleh pihak bimbingan belajar, membantu lebih memahami pelajaran disekolah, wadah siswa untuk mengkonsultasikan pemilihan jurusan yang sesuai dengan minat, bakat, dan kemampuan sehingga siswa dapat memperhitungkan persaingan dan mendapat wawasan tentang perguruan tinggi (Esagama, 2009).

Kontribusi efikasi diri yang ditunjukkan dalam tabel 10a analisis kovarian dengan $\mathrm{F}$ hitung sebesar 116.123 dan nilai signifikansi 0.000 menandakan bahwa efikasi diri secara signifikan berinteraksi dengan kecemasan. Terkait yang dikemukakan oleh Bandura (1997) mengenai efikasi diri yang merupakan suatu keyakinan yang dimiliki oleh individu secara umum dalam meregulasi dan mengorganisasikan kemampuan diri baik dalam hal kognitif, kehidupan secara sosial, emosional serta perilaku dalam tujuannya untuk mencapai apa yang diinginkan dalam hidup agar berjalan secara efektif, dapat dikatakan bahwa individu yang tidak mengikuti bimbingan belajar bukan berarti tidak siap dalam hal kognitif, mental maupun emosional dalam menghadapi ujian nasional. Keyakinan dalam diri ini lah yang membuat individu dalam kelompok yang tidak mengikuti bimbingan memiliki rata-rata kecemasan yang lebih rendah.

Dilihat dari angka signifikansi setelah adanya kontrol terhadap efikasi diri, kecemasan siswa kelas III SMA tetap mengalami perbedaan, dimana rata-rata nilai kecemasan kelompok siswa yang tidak mengikuti bimbingan belajar lebih rendah dibandingkan yang mengikuti bimbingan belajar. Hal ini dapat dilihat dari hasil penelitian yang menunjukkan kontribusi keikutsertaan bimbingan belajar setelah adanya kontrol terhadap efikasi diri lebih meningkat yaitu sebesar $33.2 \%$. Adanya hasil analisis kovarian secara signifikan $(\mathrm{F}=$ 66.953, $\mathrm{p}=0.000$ ) menunjukkan bahwa efikasi diri secara nyata berinteraksi dengan kecemasan siswa. Sehingga dapat dikatakan setiap individu memiliki keyakinan dalam dirinya ketika ingin mencapai tujuan tertentu dalam hal ini terkait ujian nasional.

Individu yang memandang ujian nasional sebagai suatu hal yang memotivasi diri dan menantang akan berusaha mencapai tujuan yang diinginkan terlepas dari bagaimana cara mereka melakukan usaha tersebut karena usaha yang dilakukan individu disesuaikan dengan kemampuan yang mereka miliki. Hal ini sejalan dengan apa yang dikemukakan oleh Bandura (1997) yaitu keyakinan diri individu dilihat dari bagaimana individu mampu menyelesaikan tugas atau pekerjaan tertentu dalam berbagai situasi dan kondisi sesuai dengan kemampuan yang dimiliki sehingga hal tersebut akan berpengaruh pada pemilihan beban tugas, usaha, ketekunan, daya juang (resiliensi) serta sejauh mana tujuan yang ingin dicapai oleh individu.

Menurut apa yang ditemukan oleh Eriany, dkk. (2014), adanya ketakutan, kurangnya rasa percaya diri serta tuntutan dan tekanan dari luar diri siswa menjelang ujian 


\section{PERBEDAAN TINGKAT KECEMASAN SISWA DITINJAU DARI EFIKAS DIRI DAN KEIKUTSERTAAN DALAM BIMBINGAN BELAJAR}

nasional mendorong siswa untuk mengikuti program yang ditawarkan oleh bimbingan belajar dengan harapan dapat mengurangi ketakutan serta kecemasan yang mereka rasakan dan membantu dalam mencapai tujuan kelulusan. Sehingga dapat disimpulkan, apabila siswa ketika mengikuti bimbingan belajar tetap membawa dan tidak menghilangkan basis rasa ketakutan dan kurang percaya diri tersebut, manfaat dari bimbingan belajar itu sendiri tidak akan maksimal dapat dirasakan oleh individu.

Kontribusi keikutsertaan dalam bimbingan belajar dan efikasi diri menunjukkan angka sebesar $33.2 \%$ yang berarti bahwa terdapat kontribusi variabel lain sebesar $66.8 \%$ yang dapat mempengaruhi kecemasan individu. Nevid (2005) mengemukakan bahwa faktor-faktor yang dapat mempengaruhi kecemasan individu diantaranya faktor biologis, tingkah laku, kognitif emosional serta lingkungan sosial individu.

Peneliti selanjutnya membahas secara lebih mendalam mengenai hubungan kecemasan dengan efikasi diri melalui analisis regresi sederhana pada tabel $13 \mathrm{~b}$ dimana terlihat koefisien regresi sebesar 0.326 dengan tanda koefisien regresi yang negatif. Hal ini berarti semakin tinggi efikasi diri maka akan semakin rendah kecemasan yang dimiliki siswa. Selain itu nilai $\mathrm{R}$ square sebesar 0.293 menandakan bahwa variabel kecemasan dapat dijelaskan oleh variabel efikasi diri sebesar 29.3\%. Sejalan dengan yang daitemukan oleh Rini (2013) bahwa efikasi diri yang dimiliki oleh siswa mempengaruhi tinggi rendahnya kecemasan siswa dalam menghadapi ujian nasional. Hal ini dapat dikatakan pula sejalan dengan yang dikemukakan oleh Supriyatin (2013) bahwa individu dengan keyakinan diri yang tinggi akan siap dan yakin untuk dapat berhasil mengerjakan tugas-tugas yang dimiliki, sebaliknya individu dengan keyakinan diri yang rendah akan merasa cemas ketika mengerjakan tugas-tugas dan cenderung mengalami kegagalan.

Uji komparasi efikasi diri yang ditinjau berdasarkan kelompok subjek yang mengikuti bimbingan belajar dan kelompok subjek yang tidak mengikuti bimbingan belajar, menunjukkan hasil yang secara signifikan identik dimana nilai signifikansi dari hasil analisis data sebesar $p=0.972(p>0.05)$. Hal ini berarti dari segi efikasi diri tidak ada perbedaan yang signifikan antara kelompok siswa yang mengikuti bimbingan belajar dan tidak mengikuti bimbingan belajar. Demikian halnya dengan skor hasil penelitian yang menunjukkan adanya kecenderungan efikasi diri seluruh kelompok tinggi, sehingga wajar apabila ada kelompok siswa yang memiliki kecemasan rendah meskipun tidak mengikuti program dalam bimbingan belajar. Hal ini dikarenakan tinggi rendahnya kecemasan tidak hanya disebabkan oleh kontribusi keikutsertaan bimbingan belajar tetapi keyakinan dalam diri individu lah yang akan berkontribusi lebih besar terhadap tujuan yang ingin dicapai. Menurut teori Bandura (1997), efikasi diri individu dilihat dari bagaimana individu yakin dengan kemampuan yang dimiliki dalam menyelesaikan tiap kesulitan tugas yang dihadapi, derajat aktivitas yang dilakukan oleh individu terkait keluasan bidang yang diyakini individu dapat dilakukan serta ketahanan individu dalam menghadapi hambatan dalam proses pencapaian tujuan tersebut. Semua ini bersumber dari dalam diri individu itu sendiri dengan diperkuat oleh situasi diluar diri individu.

Efikasi diri dikembangkan dan diperoleh dari empat sumber informasi (Bandura 1977) yaitu diantaranya a) hasil yang telah dicapai (performance accomplishment) dimana dapat dilihat dari bukti nyata hasil belajar yang telah siswa dapat di sekolah maupun di tempat bimbingan belajar, b) pengalaman yang seolah-olah dialami sendiri oleh individu (vicarious experience) yang didapat dengan melihat teman yang memiliki kemampuan setara dengan individu berhasil. Sebagian besar siswa dalam mempersiapkan ujian nasional akan membentuk kelompok-kelompok belajar atau melakukan kegiatan belajar bersama-sama sehingga tiap siswa akan memiliki figure teman yang dijadikan pembanding dalam memprediksi apakah nantinya akan sukses atau tidak dalam pelaksanaan ujian nasional, c) persuasi sosial (social persuation) yang dapat dilihat dari adanya informasi serta bujukan dari pemerintah bahwa ujian nasional di tahun 2015 tidak lagi menjadi suatu hal yang perlu ditakutkan karena tujuan dari ujian nasional itu sendiri sebagai media pembelajaran dan evaluasi belajar siswa bukan lagi sebagai penentu kelulusan, d) keadaan emosi atau fisik (emotional or psysiological) individu yang tidak terlalu mengkhawatirkan ujian nasional karena tidak lagi menjadi syarat kelulusan menjadikan individu akan lebih berfokus pada mengusahakan apa yang terbaik untuk menghadapi ujian nantinya.

Penentuan kelulusan siswa yang di tahun ini diserahkan kepada pihak masing-masing sekolah menjadi satu sumber yang dinilai cukup menyumbangkan kontribusi yang besar terhadap tingginya efikasi diri siswa. Hal ini dikarenakan siswa akan memiliki konsep pemikiran bahwa sekolah akan bertindak objektif dalam menilai prestasi belajar siswa tidak hanya dari segi mata pelajaran saja tetapi juga bagaimana kehidupan belajar yang selama 3 tahun dijalani oleh siswanya. Sehingga wajar apabila siswa memiliki keyakinan yang tinggi dalam dirinya akan sukses dalam kelulusan pendidikan akhir. Dengan demikian, setelah melalui prosedur penelitian dan analisis data yang sesuai, penelitian ini dapat dikatakan mampu mencapai tujuannya yaitu mampu mengetahui perbedaan kecemasan diantara siswa yang mengikuti bimbingan belajar dan tidak mengikuti bimbingan belajar dengan adanya kontrol terhadap efikasi diri dari siswa itu sendiri.

Adapun kesimpulan yang didapatkan dari penelitian ini yaitu diantaranya pertama, terdapat perbedaan kecemasan pada siswa kelas III SMA yang ditinjau dari efikasi diri dan 
keikutsertaan bimbingan belajar menjelang ujian nasional. Kedua, kecemasan siswa di kelompok bimbel lebih tinggi daripada kecemasan siswa di kelompok tidak bimbel. Ketiga, terdapat interaksi antara kecemasan dan efikasi diri pada analisis kovarian dan efikasi diri mampu memprediksi peningkatan dan penurunan kecemasan siswa dilihat dari hasil regresi sederhana. Keempat, tidak ada perbedaan efikasi diri di kelompok yang ikut bimbel dan tidak ikut bimbel, sehingga dapat dikatakan bahwa setiap individu memiliki efikasi diri yang identik dan cenderung tinggi dilihat dari kategorisasi skor. Kelima, kecemasan individu dalam menghadapi ujian nasional lebih didominasi oleh aspek penyusun yaitu trait anxiety yang lebih mengarah pada disposisi kepribadian dari individu.

Terdapat pula beberapa saran yang dapat dipertimbangkan dalam penelitian ini yaitu terkait saran praktis, (a) Bagi lembaga bimbingan belajar, hasil penelitian ini dapat dijadikan sumber acuan tambahan untuk meningkatkan pelayanan terutama dari segi pemberian dukungan tidak hanya materi pelajaran atau cara-cara menjawab dengan cepat tetapi juga dukungan dalam hal psikologis dari siswa-siswi yang anak didik di lembaga bimbingan belajar dengan cara membantu memfasilitasi dalam hal bimbingan konseling maupun kegiatan relaksasi secara berkala agar siswa tidak terbebani oleh mata pelajaran yang selalu diberikan. (b) Bagi pihak sekolah dan guru kedepannya bisa lebih meningkatkan pengajaran di sekolah terutama dalam hal kaitanya dengan pelajaran yang akan di ujian nasionalkan karena pendidikan formal utama yang siswa dapatkan adalah di sekolah, sehingga lebih baik apabila dari pihak sekolah yang lebih besar peranannya dalam membantu mengatasi kesulitan belajar siswanya. (c) Bagi orang tua siswa dapat memberikan dukungan tidak hanya dengan memfasilitasi anak-anak untuk ikut dalam berbagai macam kegiatan les atau belajar diluar sekolah namun dapat dilakukan dengan memberikan dukungan secara emosional misalnya dengan memberikan motivasi positif kepada anak. (d) Bagi siswa SMA, dalam pengerjaan soal-soal ujian sekiranya tidak semata-mata hanya tahu dan hafal kunci jawaban, tetapi harus yakin dapat mengerjakan dengan memahami pola-pola cara pemecahan soal sehingga siswa yakin dapat mengerjakan tipe soal apapun dengan tenang dan tidak cemas. (e) Siswa dapat meningkatkan efikasi diri salah satunya dengan mencoba beberapa pelatihan salah satunya adalah berlatih untuk berpikir positif akan dapat menghadapi dan melaksanakan ujian nasional dengan baik dan berhasil mencapai nilai maksimal.

Saran bagi peneliti selanjutnya yang juga dapat dijadikan bahan pertimbangan yaitu (a) Perbaikan alat ukur penelitian agar dapat dikembangkan lebih baik lagi oleh peneliti selanjutnya dengan penambahan jumlah aitem sehingga dapat mengungkap variabel kecemasan dan efikasi diri dengan lebih baik lagi. (b) Bagi penelitian selanjutnya dapat memperbesar sampel penelitian agar nantinya hasil penelitian dapat digeneralisasi lebih luas serta dapat menggambarkan situasi dan kondisi dari siswa kelas III SMA yang akan mengikuti ujian nasional. (c) Sekiranya dapat menambah variabel lain yang bisa dijadikan tambahan penelitian agar dapat lebih mengungkapkan faktor-faktor apa saja yang ternyata dapat mempengaruhi kecemasan siswa kelas III SMA menjelang ujian nasional. (d) Diharapkan pula agar dapat lebih mengungkapkan efikasi diri dan keikutsertaan bimbel dalam kaitannya dengan kecemasan siswa melalui metode penelitian baik itu kuantitatif maupun kualitatif secara lebih mendalam sehingga nantinya tidak hanya mendapat gambaran kontribusi efikasi diri dan keikutsertaan bimbingan belajar terhadap kecemasan saja tetapi juga bagaimana efikasi diri dan keikutsertaan bimbingan belajar secara nyata dapat memberikan pengaruh terhadap kecemasan itu sendiri serta apa yang dapat dilakukan untuk meningkatkan efikasi diri dan memaksimalkan peran dari bimbingan belajar.

\section{DAFTAR PUSTAKA}

Ant/Mba. (2012 April). Menjelang UN, Sejumlah Siswa Mengaku Cemas. Psikologizone (Internet). 15 April. Available from $<$ http://www.psikologizone.com/menjelang-un-sejumlahsiswa-mengaku-cemas/065116163>. Accessed 23 Desember 2013

Astuti, Risma Puji., Purwanto, Edi. (2014). Perbedaan Self-Efficacy Siswa dalam Menghadapi Ujian Nasional di SMP Negeri 1 Boyolali ditinjau dari Keikutsertaan Bimbingan Belajar. Educational Psychology Journal. 3(1), 20-21.

Azwar, S. (1998). Metode Penelitian. Yogyakarta: Pustaka Pelajar.

Azwar, S. (2010). Dasar-Dasar Psikometri. Yogyakarta: Pustaka Pelajar.

Azwar, S. (2013). Penyusunan Skala Psikologi Edisi 2. Yogyakarta: Pustaka Pelajar.

Bandura, Albert. (1997). Self-Efficacy: The Exercise of Control. New York: W.H. Freeman and Company.

Damanik, C. (2012, Desember). Ramai-ramai Les Pelajaran. Diunduh dari edukasi.kompas.com: http://edukasi.kompas.com/read/komentar/2012/12/07/1749 4989/Ramairamai.Les.Pelajaran 23 Desember 2013.

Durand, M.V., Barlow, D.H. (2006). Essentials of Abnormal Psychology 4th edition.USA: Thomson Wadsworth

Eriany, Praharesti., Hernawati, Lucia., Goeritno, Haryo. (2014). Studi Deskriptif Mengenai Faktor-faktor yang Mempengaruhi Motivasi Mengikuti Kegiatan Bimbingan Belajar Pada Siswa SMP di Semarang. Psikodimensia, 13 (1), 115-130. 


\section{PERBEDAAN TINGKAT KECEMASAN SISWA DITINJAU DARI EFIKAS DIRI DAN KEIKUTSERTAAN DALAM BIMBINGAN BELAJAR}

Esagama. (2009,Januari). Manfaat Bimbel. Diunduh dari http://esagama.com/?pilih=news\&mod=yes\&aksi=lihat\&id $=1810$ Mei 2014 .

Fauzy, A. R. (2013, Oktober 16). Bimbingan Belajar, Perlu atau Tidak? Diunduh dari inilahkoran.com: www.inilahkoran.com/read/detail/2038792/bimbinganbelajar-perlu-atau-tidak 21 Desember 2013

Ghozali, Imam. (2011). Aplikasi Analisis Multivariate dengan Program IBM SPSS 20. Edisi 6. Semarang: Badan Penerbit Universitas Diponegoro.

Hadi, Sutrisno. (1991). Statistik 2. Yogyakarta: Andi Offset.

Kartika, P. (2013). Perbedaan Tingkat Stres Pada Ibu Rumah Tangga yang Menggunakan dan Tidak Menggunakan Pembantu Rumah Tangga. (Skripsi Tidak Dipublikasikan). Ps. Psikologi, Fakultas Kedokteran UNUD, Denpasar.

Kumaraswamy, Narasappa. (2013). Academic Stress, Anxiety and Depression Among College Student - A Brief Review. International Review of Social Sciences and Humanities, 5(1), 135-134.

Nevid, J.S., Rathus, S.A., \& Greene, B., (2005). Psikologi Abnormal. Edisi Kelima. Jilid I. Alih Bahasa: Jeanette Marad, dkk. Jakarta: Erlangga.

Nugroho, N. (2010). Perbedaan Tingkat Kecemasan Siswa Kelas XII yang Mengikuti Bimbingan Belajar dengan yang Tidak Mengikuti Bimbingan Belajar dalam Menghadapi UN di SMAN 2 Sragen. (Skripsi Tidak Dipublikasikan). Fakultas Kedokteran Universitas Sebelas Maret, Surakarta.

Nurgiyantoro, B., Gunawan, \& Marzuki. (2009). Statistik Terapan: Untuk Penelitian Ilmu-ilmu Sosial. Yogyakarta: Gadjah Mada University Press.

Pratiwi, Amalia Putri. (2009). Hubungan Antara Kecemasan Akademis dengan Self-Regulated Learning Pada Siswa Rintisan Sekolah Bertaraf Internasional di SMA Negeri 3 Surakarta. (Skripsi Tidak Dipublikasikan). Fakultas Psikologi, Universitas Diponegoro, Semarang.

Purwanto. (2008). Metodologi Penelitian Kuantitatif untuk Psikologi dan Pendidikan. Yogyakarta: Pustaka Pelajar.

Riduwan, Rusyana, Adun., \& Enas. (2011). Cara Mudah Belajar SPSS 17.0 dan Aplikasi Statistik Penelitian. Bandung: Alfabeta.

Rini, Harfiahana Puspa. (2013). Self-Efficacy dengan Kecemasan dalam Menghadapi Ujian Nasional. Jurnal Online Psikologi, 1(1), 34-35.
Rustika, I Made. (2014). Faktor-faktor yang Mempengaruhi Prestasi Akademik pada Remaja.(Disertasi Tidak Dipublikasikan). Universitas Gadjah Mada, Yogyakarta.

Salkind, Neil J. (2010). Covariate. Ensyclopedia of Research Design Journal. Diakses tanggal: 1 Februari 2015 pada situs http://srmo.sagepub.com

Santoso, S. (2003). Mengatasi Berbagai Masalah Statistik dengan SPSS versi 11.5. Jakarta: Elex Media Komputindo.

Santrock, J.W. (2007). Psikologi Pendidikan. Terjemahan: Wibowo, T. Jakarta: Kencana Prenada Media Group.

Slavin, Robert E. (2009). Educational Psychology: Theory and Practice 9th Edition. New Jersey: Pearson

Spielberg, C.H. (2006). The State-Trait Anxiety Inventory. New York: Oxford University Press.

Sugiyono. (2013). a) Metode Penelitian Kuantitatif Kualitatif dan R\&D, b) Statistika untuk Penelitian. Bandung: Alfabeta, CV.

Supriyatin, V.R. (2013). Meningkatkan Efikasi Diri Melalui Layanan Bimbingan Kelompok dengan Teknik Diskusi Kelompok pada Sisa Kelas VIII SMP Negeri 5 Semarang Tahun Pelajaran 2012/2013. (Skripsi Tidak Dipublikasikan). Program Studi Psikologi Pendidikan dan Bimbingan Fakultas Ilmu Pendidikan IKIP PGRI Semarang, Semarang.

Suryadi, B. (2013). Evaluasi Penyelenggaraan Ujian Nasional Tahun 2013. Jakarta: Fakultas Psikologi UIN Syarif Hiddayatulah.

Taylor, Shelley E., et. al. (2009). Psikologi Sosial, Edisi Kedua Belas. Jakarta: Kencana.

Yuwono, S. (2009). National Examination and Playing Time of Children . (Tesis Tidak Dipublikasikan). Fakultas Psikologi Universitas Muhammadiyah, Surakarta. 